\title{
Negro é o sol da peste
}

\author{
https://doi.org/10.21814/uminho.ed.23.12
}

\section{Maria do Rosário Girão Ribeiro dos Santos}

Maria do Rosário Girão Ribeiro dos Santos (ORCID: 0000-0001-8723-5985) é Professora Associada do Departamento de Estudos Românicos do Instituto de Letras e Ciências Humanas e investigadora do CEHUM. Doutorou-se na Universidade do Minho com uma tese intitulada "À sombra de Baudelaire. Estudo da receção de Baudelaire na Literatura Portuguesa. Do romantismo ao modernismo". Encontra-se, atualmente, a redigir um ensaio intitulado "O retrato do artista na ficção".

\section{Manuel José Silva}

Manuel José Silva é Professor Associado aposentado do Instituto de Letras e Ciências Humanas. Publicou as seguintes obras: "La langue française et l'histoire" (2008); "O voo do garajau: dos Açores a Macau” (2014), de parceria com Maria do Rosário Girão Ribeiro dos Santos; "El-Rei D. Sebastião: (re) olhares” (2017). Encontra-se, atualmente, a redigir uma obra sobre Nostradamus intitulada "A propósito de Nostradamus, médico, historiador e astrófilo". 
Desde os tempos primordiais que o homem tem vindo a ser perseguido, sob a canícula ou a invernia, por um mortífero companheiro de estrada, inimigo invisível, fantasma letal, candidato a hóspede de um qualquer hospedeiro desprevenido. Visitante oculto diversamente nomeado (micróbio, bactéria e vírus ${ }^{1}$ ), eis que se firma como responsável de endemias, epidemias e pandemias, entre as quais figuram o tifo, a varíola, a cólera, a sífilis e a peste ${ }^{2}$. Numa lúgubre digressão turística, relembrem-se as pestes bíblicas $^{3}$, a peste de Justiniano ${ }^{4}$, a peste negra ${ }^{5}$ e a peste de Marselha ${ }^{6}$. Atualize-se, advindos do nosso imaginário, tanto o trajo de um médico do lazareto de Marselha, em cujo 'bico' eram depositadas ervas aromáticas, passíveis de uma eventual imunização, quer o do cirurgião armado de longas tenazes adequadas ao transporte de cadáveres pestíferos. Revisite-se, face à doença causada por "Yersinia Pestis", a atitude do ser humano estonteado: a fuga a pé ou a cavalo, por via terrestre ou marítima; a mortificação e flagelação, invocando a clemência de um Deus redentor e não punitivo; a sistematização da quarentena e da política sanitária, em finais do século XVI; a crescente higienização

1 A este respeito, afigura-se oportuno estabelecer uma breve e constrangedora distinção entre o micróbio, que, passível de desenvolvimento em estados sanitários medíocres, não conduz à epidemia, a bactéria que, estudada por Louis Pasteur, se reproduz por divisão e o vírus, que se multiplica no seio de uma célula e é conhecido pela sua capacidade de mutação e propagação célere. Ver Les Épidémies, 2017, p. 32-33.

$2 \mathrm{O}$ termo peste, que vem do latim pestis (praga), coexiste, no século XVII, com o de epidemia, forjado a partir de epi (sobre) e démos (povo) e significando "doença que se abate sobre o povo".

3 Cf. Êxodo 8-9, VI. "As úlceras": "Disse Iahweh a Moisés e Aarão: Apanhai mãos cheias de cinza de forno e Moisés a lance para o ar, diante dos olhos de Faraó. Ela se converterá em pó fino sobre toda a terra do Egito e provocará, nos homens e nos animais, tumores que se arrebentem em úlceras, por toda a terra do Egito. [...] e os homens e os animais ficaram cobertos de tumores que se arrebentavam em úlceras." Ver, também, V. "A peste dos animais" (1981, p. 88). Ver, por fim, II Samuel 23-24, "A peste e o perdão divino”: "Iahweh mandou a peste a Israel [na sequência da escolha de Davi] [...] O flagelo feriu o povo, e setenta mil homens do povo morreram, desde Dã até Bersabéia.” (1981, p. 343).

4 Por volta de 542 deflagrou uma epidemia que destruiu quase todo o género humano, tendo sido descrita por Procope, historiador bizantino do Imperador Justiniano (482-565) e por Grégoire de Tours (cujo nome foi dado a uma rua de Paris, na "rive gauche").

5 Praticamente esquecida desde os Merovíngios, esta peste bubónica, trazida da Ásia central por marinheiros italianos, constituiu, nessa época, uma praga bem maior do que a guerra. Alastrou-se, em França, de 1347 a 1349, conhecendo um novo surto em 1361 (Guinle, 1997, p. 152).

6 Em La Peste, o Padre Paneloux lembra aos seus fiéis que o cronista invisual Mathieu Marais se queixara de haver mergulhado no inferno durante a grande peste de Marselha (Camus, 1996, p. 95). 
oitocentista, passando pela aquisição de bons hábitos, pela desinfestação de ruas e desinfeção de domicílios; presentifique-se, ao longo dos tempos do Tempo, a formulação de teorias e a aparição de descobertas tendentes para a identificação e a erradicação do mal. Hipócrates (460-377 a.C.), em Epidemias, afirma de modo categórico que estas últimas irrompem, de um modo geral, na "bela estação", estabelecendo destarte um elo entre o clima e a epidemiologia; Tucídides (465-395 a.C.), precursor da ciência histórica, descreve a peste de Atenas e a praga do Egito na História da guerra do Peloponeso (confronto entre Esparta e Atenas); Lucrécio (99-55 a.C.) expõe e retoma, no seguimento de Tucídides, a origem e os danos da peste, em De natura rerum; no Renascimento, Girolamo Fracastoro, cuja pesquisa incide sobre a peste e a sífilis, é o primeiro, em $D e$ contagione et contagiosis morbis et eorum curatione (1546), a atribuir aos micro-organismos (revelados, no “Século das Luzes”, graças à invenção do microscópio), não visíveis a olho nu, a causa da epidemia, avançando com a primeira teoria do contágio; em finais de Setecentos, François Broussais forja o conceito de "foco infecioso", remetendo para a putrefação cadavérica e para a promiscuidade reinante em aglomerados humanos; sobrevoando Oitocentos, Jakob Henle e Robert Koch surgem como os 'pais' da microbiologia humana, descobrindo, o segundo, o bacilo da tuberculose, batizado com o seu apelido; em finais do século XIX, Alexander Yersin, aluno de Louis Pasteur, dá a conhecer a bactéria da peste, à qual também é dada o seu nome, enquanto Paul-Louis Simond demonstra o papel desempenhado pelas pulgas no contágio do homem pelos ratos. E, sendo "costume considerar-se a literatura como espelho da vida, uma forma de âncora com a realidade, a sociedade, a cultura e a história” (Cabral, 2020, p. 27), registe-se, numa síntese confrangedora, o elenco considerável de escritores que glosaram o tema pandémico, mediante testemunhos colhidos na experiência de outrem e na consulta de documentos vários, citados, adaptados ou transpostos metaforicamente. Sófocles, em Édipo-Rei, refere-se à peste maldita como a uma praga caída do Céu; François Rabelais, em Gargantua, reporta-se à intrusão da peste nas casas; Giovanni Bocaccio, no Decameron, recorre à quarentena como tela de fundo de cem histórias, contadas, numa vila isolada de Florença, a fim de fugir da peste, por sete raparigas e três rapazes, que assim pintam os costumes licenciosos da sua época; Jean de La Fontaine escreve no Livro VII a fábula "Os animais doentes da peste", caraterizando esta doença como um mal que espalha o terror e que foi inventado para castigar os crimes da terra; Gustave Flaubert 
escolhe, igualmente, uma Florença enlutada, varrida pelo povo que blasfema contra Deus e amaldiçoa os Seus ministros, como cenário de uma rivalidade mortal entre dois irmãos, filhos de Cosme de Médicis, gerada pela predição da sexagenária Beatricia; na novela de Edgar Allan Poe, intitulada "O Rei Peste" e traduzida por Charles Baudelaire, o leitor é informado de que o demónio da peste havia escolhido, como local da sua natividade, os bairros pobres nas imediações do Tamisa, bem como as ruelas estreitas e as passagens imundas. Transitando para a contemporaneidade, verifica-se que o ensaio e a ficção, a História e a Literatura, perseveram na abordagem da epidemia: atente-se em The Great Influenza, de John M. Barry, no saramaguiano Ensaio sobre a Cegueira e na obra coletiva Centenário da gripe pneumónica. Recuando, porém, até ao ano de 1947, realce-se a originalidade de um "clássico" " que fez e faz História na atualidade: $L a$ Peste de Albert Camus.

Aquando da receção deste romance camusiano pela crítica, Roland Barthes procedeu a uma exegese dúbia, repassada de algumas reservas. Assim sendo, no primeiro artigo dado ao prelo sobre L'Étranger, publicado em 1944 na revista Existences, o supracitado semiólogo denuncia, por um lado, a contradição aparente entre um livro que não tem estilo, conquanto esteja bem escrito e louva, por outro, o silêncio da escrita, bem como a sua adequação à problemática do absurdo. Ora, em 1955, oito anos após a publicação de La Peste (galardoada em 1947 com o "Prix des Critiques”), não hesita em verberar a insuficiência da moral que subjaz ao romance - "moral de amigos" -, nos antípodas de um comprometimento, ou seja, de uma solidariedade militante (Barthes, 1993, p. 40-54). Afiguram-se óbvias, neste contexto, quer a rejeição barthesiana do simbolismo, da metaforização e da alegoria nazi, quer a opção pela crónica, demasiado geral e abstrata, desaguando numa fábula anti-histórica, protagonizada por "seres de papel” incapazes de enfrentar o inimigo ou de lhe opor a mais viva resistência. A resposta do nono escritor francês, que viria a receber dois anos mais tarde, em 1957, o Prémio Nobel, é, a todos os níveis, firme e clarividente, constituindo uma base sólida

\footnotetext{
7 Segundo Italo Calvino (2018, p. 7-17), "clássico" é o livro do qual se ouve dizer 'Estou a relê-lo" e do qual nunca se diz "Estou a lê-lo"; é, igualmente, o livro que exerce uma influência particular ao firmar-se como inesquecível e ao dissimular-se nas dobras da memória por assimilação ao inconsciente individual e coletivo; é, por fim, o livro que nunca acabou de dizer o que tem para dizer.
} 
para estudos literários vindouros (Camus, 2006, p. 285-286). Numa etapa inicial, Albert Camus, embora considere legítimo qualquer comentário de boa fé, refuta a moral anti-histórica e a política de solidão, apontadas por Barthes ${ }^{8}$ e conducentes a óbvias contradições. Em primeiro lugar, assevera que a obra em apreço deve ser objeto de uma leitura plural (e não de uma única leitura), apresentando os seguintes argumentos: a publicação de uma longa passagem de La Peste, sob a Ocupação e subsequente transposição operada; a existência de um inimigo inominado, por ser conhecido e reconhecido à saciedade; o conteúdo evidente da resistência europeia contra o nazismo, aplicável, de um modo mais concreto ou numa perspetiva mais abstrata, a "todas as resistências contra todas as tiranias”. Em segundo lugar, sublinha a evolução de La Peste no que respeita a $L$ 'Étranger: enquanto a primeira narrativa se debruça sobre o reconhecimento de uma comunidade, em que a luta é partilhada, a segunda tem como alicerce uma atitude de revolta individual e solitária. Em terceiro lugar, realça a importância crucial do tema da separação, ou seja, da renúncia à vida privada em prol da participação dinâmica no combate coletivo, enfatizando a facticiedade da oposição entre "amigo" e "militante". Em quarto lugar, destaca o explicit do romance, arauto da aceitação dos combates a serem posteriormente travados. Repudia, por fim, a sua 'instalação' numa carreira solitária, em proveito de uma vivência ao serviço da comunidade. Marginalizando a polémica, sempre louvável porquanto torna manifestos pontos de vista que, em caso contrário, não pisariam "as luzes da ribalta”, ilícito não se torna trazer à liça o existencialismo de Camus, podendo ser definido como a relação entre o absurdo da existência e a sua neutralização, mediante o humanismo, suscetível de conduzir o ser humano à prática do bem. Não constituirão a revolta instintiva, a moral da responsabilidade e a mútua solidariedade armas eficazes para vencer o absurdo, nas suas vertentes de alheamento e exílio? Nesta conjuntura, é inegável que Le Mythe de Sisyphe ilumina o romance em apreço no tocante à sensibilidade absurda ou, mais bem dito, ao confronto, e subsequente rutura, entre o apelo do ser humano e o silêncio do mundo, ao divórcio entre o homem e a vida, o ator e o cenário (Camus, 2003, p. 20), à ausência de

\footnotetext{
8 Roland Barthes coloca ainda uma outra questão a Camus: "O que fariam os combatentes de $A$ Peste perante inimigos humanos?" A réplica de Camus (dada ao prelo em Club, fevereiro de 1955), que não gostava de evocar as suas atividades clandestinas de combatente, não tarda a chegar: "Essa questão é injusta, no sentido em que ela deve ser escrita no passado e já teve uma resposta positiva.” (Camus, 2006, p. 285-286).
} 
objetivos ou descrença no futuro (idem, p. 82) e à sensação de estranheza num universo que, carecido de ilusóes ou de luzes (idem, p.20) e privado de "recordações de uma pátria perdida e esperança numa terra prometida”, gera o sentimento irreversível de desterro. Posto que "viver, naturalmente, nunca é fácil” (ibidem), a tenacidade e a clarividência surgem como espetadores privilegiados deste jogo desumano em que o absurdo, a esperança e a morte se afrontam, em diálogo ou em conflito. Assim é que Sísifo surge como o herói absurdo, o símbolo do homem que, consciente desse mesmo absurdo, o tenta superar, dominando o seu destino que consiste na elevação, até ao cume de uma montanha, de uma rocha que, incessantemente, lhe vai escapando e que, de contínuo, ele retoma na planície para de novo a içar: "O homem absurdo diz sim [...] a própria luta rumo aos cimos é suficiente para encher um coração humano. É preciso imaginar Sísifo feliz.” (idem, p. 168).

À imagem e semelhança de Sísifo, não responderão afirmativamente ao seu destino as personagens de La Peste? E não será o recurso à alegoria a assegurar a síntese entre o destino filosófico e a ficção literária? (Paveau, 1996, p. 51) Neste contexto, a peste camusiana, fenómeno concreto, volve-se em metáfora da condição humana ou, por outras palavras, da doença moral e social que assola a Humanidade, no que respeita à defesa da pena capital, caucionada por alguns dos seus membros, ao determinismo mórbido conducente à prática do mal (idem, p. 228), ao assassínio encarado como uma prática natural e à tara de que cada homem é portador: "Mas, o que é que isso quer dizer, a peste? É a vida, eis tudo"; "cada um traz em si a peste” (Camus, 1996, p. 278 e 228).

De facto, o romance em pauta, num magistral jogo de espelhos, tanto pode ser alvo de uma interpretação literal, sócio endémica ${ }^{9}$, como de uma outra metafórica, histórico-política ${ }^{10}$, mediante a intrusão de cenários lúgubres, palco distópico de eventos que o sofrimento e a morte protagonizam. É o caso do número crescente de ratos

9 Ver a epígrafe de Daniel Defoe, Autor de A Journal of the Plague Year (1722), reportagem inquietante sobre a epidemia de peste bubónica que dizimou muitas vidas em Londres.

10 Atentar nas Lettres à un ami allemand, bem como no "Prefácio à edição italiana", onde o Autor explica que, ao referir-se a "vous" (vós), refere-se aos nazis, e, ao empregar "nous" (nós), dirige-se aos europeus livres (2002, p. 16). 
mortos: no princípio, era um rato (idem, p. 15); sucederam-se-lhe centenas de cadáveres de ratos (idem, p. 21), seis mil duzentos e trinta e um ratos queimados (idem, p. 22) e cerca de oito mil ratos (idem, p. 22-23); do encerramento das portas de Orão ${ }^{11}$ ou da cerca sanitária impositiva de um confinamento obrigatório; da luz crepuscular dos cafés, em virtude da iluminação pública reduzida; dos novos imperativos sociais e administrativos, prescrevendo tanto a quarentena (nos domicílios e nos hotéis) ou a interdição de sair, punível com ameaças de prisão (idem, p. 107), como o racionamento de géneros e as restrições culturais (apesar de, na representação de Orfeu e Eurídice, Orfeu ir ao encontro da morte em cena); da extensão das filas, serpenteando em redor das lojas, da emergência do mercado negro e da ascensão dos contrabandistas; do monumento aos mortos, sito no único lugar de onde se avista o mar; da morte massiva, visível na supressão das pompas funerárias, na exiguidade confrangedora dos cemitérios (e seus 'avatares'), na insuficiência de sepulturas individuais, no recurso a valas comuns (que vão, gradualmente, desrespeitando a separação dos géneros) e no fumo negro dos crematórios; do uso de ventiladores e de máscaras, que "não são apenas pedaços de tecido ou de papel que nos protegem de gotículas pestilentas" ou que nos remetem "ao anonimato dos corpos” (Cabral, 2020, p. 25) ${ }^{12}$.

Com o intuito de acentuar a fragilidade do pascaliano "roseau pensant” / junco pensante” que é o Homem, Camus põe em cena esta dúbia endemia pestífera, que se alastra na cidade argelina de Orão, de 30 de abril de 1940, a 25 de janeiro do ano seguinte. Este tempo romanesco, abrangente, vê-se escandido pela cronologia da peste, ritmada por indícios temporais que atestam a sua trajetória sazonal: a "primavera da peste" (idem, p. 181), a terceira semana da peste e a quinta semana da peste (idem, p. 77). O Dr. Bernard Rieux, porta-voz camusiano, assume-se tardiamente, no desfecho, como narrador (um segundo narrador, sendo o narrador principal o seu criador) da crónica ficcional da pestilência, desde a sua génese e evolução até à sua estabilidade e término. Nesta crónica, que pode ser definida com um registo circunstancial, osmose

11 Saliente-se que Albert Camus, "Argelino da terceira geração" (citando as suas palavras), escreve o seu primeiro ensaio sobre Djémila (em Noces) e situa a ação de L'Étranger em Argel.

12 "Hoje, como nos primórdios teatrais da Cidade Antiga, a máscara não deve esconder, mas dar a ver [...] o homem face à Cidade, face à natureza, face à transcendência, face a si-mesmo.” (Cabral, 2020, p. 25). 
de jornalismo e de literatura, a cargo de um cronista-repórter que, sob uma anónima aparência da superficialidade, vai captando, de um modo lábil e incisivo, as situações na sua transitoriedade, ou seja, esse instante brevíssimo que faz parte da condição humana (Sá, 2008, p. 11), perpassam outras minicrónicas como o incipit do romance de Grand, do qual, absurdamente, apenas será conhecida a primeira frase, e os Carnets de Tarrou. "Mise en abîme” do trabalho artesão do sujeito escrevente (Camus), bem como dos "estertores estilísticos” do escritor ficcional (Grand), este começo de um romance a vir, mas que nunca virá, remete para a indecisão da personagem em foco, que renuncia à panóplia de dúvidas e hesitações lexicais a partir do momento em que ingressa no secretariado das formações sanitárias: "Ele tinha dito sim", esclarece o narrador, como Sísifo (acrescentamos nós). Relativamente aos Carnets de Tarrou, cronista de um período conturbado e historiador do que não tem história (idem, p. 29), é mister não olvidar o seu caráter heteróclito, albergando descrições detalhadas, pormenores ínfimos que, embora secundários, não deixam de ser relevantes, fragmentos conversacionais colhidos nos elétricos e indicações sobre histórias de ratos e gatos. Um dos extratos mais aliciantes da sua autoria é, sem dúvida, a descrição realista-humorística-satírica (num registo que contrasta com aqueloutro da pestilência intrusa) de um dia em Orão sob o negro sol da peste: às 06:00, veem-se filas, à porta dos armazéns (uma hora antes da sua abertura), para a compra de jornais, sobretudo do Courrier de l'Épidémie, que, em vez de dar conhecimento do avanço ou recuo pestíferos, publica anúncios sobre produtos novos e profiláticos; os elétricos passam atulhados e descarregam passageiros ansiosos pela paragem; os bares e cafés abrem as portas, não sem antes informarem os clientes de que "Já não há café” e pedirem-lhes “Tragam o vosso açúcar"; às 11:00, uma parada de jovens invade as artérias principais e as avenidas, munidos dessa paixão de viver que cresce no seio das grandes infelicidades; às 12:00, os restaurantes enchem-se, após afixarem uma informação tranquilizadora: "Ici, le couvert est ébouillanté"13; pelas 14:00, assiste-se ao esvaziamento da cidade e à intrusão do silêncio, do pó e da peste; ao fim do dia, pela noitinha estival, tenteia-se de novo a saída, apesar de um ancião inspirado exclamar, em vão, que "Deus é grande, venham a ele" (idem, p. 113-114). E Tarrou conclui que os

13 No sentido de serviço de mesa (pratos, copos e talheres) limpo e desinfetado. 
transeuntes se precipitam para qualquer outra coisa que se lhes afigura "mais urgente do que Deus” (idem, p. 114).

Tendo como guia o Dr. Bernard Rieux visualizamos não só a cidade de Orão banal, feia e desprovida de pombos, árvores e jardins (idem, p. 11) -, cujo turismo se vê arruinado (idem, p. 110), mas também os espaços, sãos e malsãos, da peste, detentores de uma simbologia que não passa desapercebida: o mar, símbolo de vida, de purificação e de regeneração, interdito aos habitantes por se encontrar, talvez, nos antípodas da peste, emblema de morte, de conspurcação e de degenerescência; o terraço do velho asmático, sobrepondo-se ao porto invisível e abrindo-se para um horizonte onde o céu e o mar se fundem numa "palpitação indistinta"; a rua e o bairro, calcorreados pelo autor da crónica - constantemente solicitado por doentes -, que nunca como até então se considerara tão vergado ao peso do seu sacerdócio médico; a estação de caminho de ferro, um não-lugar, segundo Marc Augé, símbolo menos da chegada do que da partida, e, por conseguinte, da separação inelutável; e, depois, o hotel, que tem como único hóspede o intelectual Tarrou, os hospitais, o estádio e as casas particulares que, por albergarem os infetados, deveriam estar "fechadas e desinfetadas" (idem, p. 63). Por um lado, a redenção inalcançável; por outro, a palpável perdição. Não deixa de ser pertinente analisar, neste universo minado pela pestilência, as reações de alguns "seres de papel” (“os nossos cidadãos”) perante a crise epidémica, bem como as relações que mantêm entre si e com o narrador-cronista.

Torna-se curioso, nesta ordem de ideias, o facto de Camus ter convocado personagens-tipo (o jornalista, o funcionário da Câmara, o intelectual, o padre e os médicos), que se afiguram menos 'tipos' do que personagens 'redondas', dotadas de uma extrema complexidade e capazes de uma transformação radical. O jornalista Rambert vem a Orão com o objetivo de investigar, para um grande jornal parisiense, as condiçôes de vida dos Árabes (ausentes do romance em proveito dos Europeus) e pedir informações acerca do seu estado sanitário. Na sequência do encerramento das portas e do confinamento obrigatório, Rambert, retido numa cidade onde é estrangeiro e prisioneiro num país que lhe é estranho, sente a dor do exílio (físico, moral e psicológico) por tempo incerto, perdendo tempo a ler na estação antigos horários e a revisitar alguns "lugares de memória” (na terminologia de Pierre Nora) parisienses, vivendo com e de 
uma memória doravante inútil: os pombos do "Palais Royal", a "Gare du Nord" e os bairros desertos do Panteão (idem, p. 104). Recorrendo a expedientes de fuga, viabilizados por Cottard e ratificados pelo Dr. Rieux, em nome da felicidade inerente ao reencontro conjugal, acaba por refutar a almejada partida e transita da revolta singular para a participação dinâmica numa causa coletiva. E, a fim de colmatar a lonjura sentimental, ei-lo a escrever cartas de amor à esposa, género epistolar que o médico-narrador dá a sensação de praticar algo desapaixonadamente, obcecado pela redação da sua crónica e pela cura dos empestados. Diversamente de Rambert, o doutor Castel (investigador tenaz cuja obstinação leva à descoberta da cura do mal) e a sua consorte, brutalmente separados e incertos quanto ao grau de satisfação carreado por uma longa união matrimonial, virão a compreender, graças a este afastamento, que não podem viver longe um do outro, sobrelevando esta verdade racional a obsessão doentia veiculada pela peste (idem, p. 70).

Um outro caso de separação é o de Grand, que não acusa a companheira Jeanne por haver partido, mas antes se culpabiliza por lhe não ter dado a devida atenção, exigida pelo amor, de que era ou julgava ser merecedora. Não se torna, aliás, despicienda uma referência, por sucinta que seja, ao discurso metalinguístico de Grand (considerado por Rieux o herói, a haver heroísmo) e, consequentemente, ao do narrador. $\mathrm{O}$ incipit do seu romance (detentor de uma frase única), persistentemente trabalhado e reformulado e modelado, dá a sensação de se situar nos antípodas da crónica, tanto pelo incumprimento da objetividade que subjaz a este género, como pelo recurso a espaços e figurantes que parecem remeter para tempos idos. "Por uma bela manhã de maio, uma esbelta amazona, montada num soberbo alazão, percorria as áleas floridas do Bosque de Bolonha.” (idem, p. 127). O questionamento lexical de Grand não se afigura tão absurdo quanto parece, numa análise superficial, não só pelo facto de se alicerçar na procura do termo justo, mas também por fazer a apologia das palavras que falam, que pintam o concreto e fotografam o mundo. Desassossegado e apreensivo no respeitante à busca permanente de um léxico ideal, interroga-se a personagem sobre o adjetivo “soberbo", não 'falante' e não correspondente à sua ideação, insubstituível por "gordo", pejorativo em demasia, ou por "reluzente", desajustado ao ritmo, até que, num momento de epifania (a que outros similares se irão sucedendo de modo 
circular), tropeça no lexema "negro", conotando, sob o seu ponto de vista, a elegância do alazão. No decurso do romance é contagiado pela peste, reclama a destruição de cinquenta páginas, rabiscadas com versões e variantes sucessivas da frase inicial, vê-se poupado miraculosamente à epidemia (prémio ou recompensa pelo sacrifício?), escreve, finalmente, à esposa, para que ela possa ser feliz, e aceita a sua primeira frase, mediante a supressão de todos os adjetivos.

Passando da “arte de bem escrever” à “arte de bem pregar”, debrucemo-nos sobre os sermões da figura inesquecível do Padre Paneloux. Relativamente ao primeiro sermão, saliente-se o exórdio, significativo a todos os níveis: "Meus irmãos, vós viveis na infelicidade, meus irmãos, vós mereceste-la.” (idem, p. 91). Ao longo do seu discurso, Paneloux insiste sobre o facto de a peste fazer parte da criação divina, estar integrada no sistema religioso e ser uma das pragas a que recorreu Deus para separar o trigo do joio, os justos dos maus ${ }^{14}$, os eleitos dos chamados. Faz, assim, ressaltar a justiça inatacável de Deus, que surge como a face terrível da Sua misericórdia divina, volvendo-se cada sofrimento infligido numa prova de amor (e o amor a Deus é difícil). As referências culturais a figuras bíblicas de maldição e a cidades destruídas (comprovando a sua eloquência e o seu dogmatismo) exemplificam a sua teoria: Pharaon, Caim, Sodoma e Gomorra e "todos os malditos" (idem, p. 94). No seu segundo sermão, proferido na catedral, Paneloux, embora num tom inicialmente hesitante, propõe a fé absoluta em Deus como única solução: “É necessário crer em tudo ou tudo negar” (idem, p. 204). E quem ousará renegar Deus? A razão desta evolução em mais não reside do que na morte do filho do Juiz Othon, o pequeno Philippe, que falece na maior das agonias, e que se encontra na base de um diálogo crucial entre Paneloux e o Dr. Rieux: por um lado, a revolta do médico face à morte de um inocente. Como podem ser as crianças punidas? Que pecado cometeram para tanto sofrerem? ${ }^{15}$ Não será o seu castigo incompreensível? Por outro lado, a perseverança do Padre, que insiste no dever de amar o que é incompreensível. Ainda por um lado, a impossibilidade, por parte do Dr. Rieux, de

\footnotetext{
14 Numa carta endereçada a Jean Grenier e datada de 21 de janeiro de 1948, Camus afirma que "o homem não é inocente e não é culpado. [...] O que 'Rieux (je)' quer dizer é que urge curar tudo o que se pode curar - à espera de saber ou de ver. É uma atitude de espera e Rieux diz 'eu não sei.”’ (La Peste, dossier, 2013, p. 686). 15 Ver, sobre este assunto, Gaillard, 1972, p. 37.
} 
amar uma criação em que as crianças são torturadas; por outro lado, a importância da salvação do homem para Paneloux e da saúde humana para o médico (idem, p. 199). Afinal, a peste firma-se, para este último, uma “interminável derrota” (idem, p. 121), à semelhança de Paneloux, que acaba por falecer, preservando a sua fé em Deus (mas deixando de a propagar, devido ao seu passamento) e refutando qualquer tipo de ajuda racional, médica e humana.

Urge, neste contexto, assinalar que, entre os dois sermões, a população de Orão prefere trazer medalhas protetoras e amuletos de $S$. Roque ${ }^{16}$ do que ir à missa. É o tempo imoderado do culto das profecias, dadas ao prelo nos folhetins dos periódicos: umas apoiavam-se em cálculos bizarros, no número de óbitos e na passagem dos meses enegrecidos pela peste; outras estabeleciam paralelismos entre as grandes pestes da História, em busca de analogias reveladoras ou de ensinamentos eficazes, com vista não a debelar o mal presente, mas a apaziguar os seus 'espetadores' impotentes. De entre os profetas, Nostradamus e Sainte Odille eram consultados diariamente, carreando a sua consulta resultados positivos no tocante a um crescendo de serenidade possível.

Não deixa de ser interessante abordar, de modo breve e conciso, a obra (bem como alguns biografemas) de Nostradamus, que nasceu em Saint-Remy-de Provence em 1503 e faleceu em 1566 na cidade de Salon (no Sul da França). Os seus pais e avós, de origem judaica, converteram-se ao Catolicismo e exerceram a sua profissão na administração pública, sendo pessoas muito estimadas. Nostradamus, nome que adotou, possivelmente, em homenagem à língua latina, que dominava, fez os seus estudos superiores na Universidade de Montpellier, inscrevendo-se no curso de medicina. Os seus mestres nunca aceitaram a sua maneira de ser nem o seu método de trabalho. Com a chegada da peste, interrompeu os estudos e começou a tratar os doentes infetados. Foi, porventura, o primeiro a impor medidas sanitárias severas, como a limpeza e o arejamento das habitações, a lavagem das roupas e a higienização das ruas, a utilização de um pó branco e de uma espécie de pílula rósea, de cuja constituição se recusou a falar. Os presidentes dos municípios do sul de França solicitavam frequentemente os

$16 \mathrm{~S}$. Roque, nascido em 1350, cursou medicina, duzentos anos antes de Nostradamus, e curou os doentes infetados pela peste, com a ajuda de Deus. Foi canonizado, ao contrário de Nostradamus, acusado de recorrer a métodos algo diabólicos (Samson, 2010, p. 17). 
seus serviços quer para medicar os infetados, quer para prevenir a peste. Contudo, o seu trabalho não foi bem acolhido pela classe médica, que o criticava por não ser doutorado em medicina. Nostradamus não curava os enfermos que se encontravam numa situação mais grave, procurando, sobretudo, proteger a população e estar na linha da frente do combate. Não tendo sido, o que é curioso, contagiado, foi, no entanto, incapaz de salvar a esposa e os filhos. Profundo conhecedor da História e imagem perfeita do erudito renascentista, revelou um interesse singular pela astrologia, pela História e pela geografia. Sendo historiador e profeta, não só revisitou muitos eventos que se passaram na Europa, embora de um modo obscuro, desaguando numa difícil interpretação, mas profetizou o que ainda não acontecera. A primeira edição de As Centúrias (existem cerca de cento e setenta edições) foi publicada em 1555 e é constituída por dez centúrias, contendo cada centúria cem quadras, exceto a sétima, que tão-só engloba quarenta e duas. É de registar, na obra em pauta, a ausência de ordem cronológica bem como de progressão temática. Assim sendo, é natural que haja não poucas dificuldades no que diz respeito à sua hermenêutica, porquanto o Autor tornou, voluntariamente, as suas quadras nebulosas, com o intuito de evitar a perseguição por parte das autoridades e da Inquisição, que o consideravam bruxo e charlatão, mágico e herege. Porém, os Reis de França, em particular Catarina de Médicis e os seus filhos, protegeram-no. A vertente profética deste astrófilo parece incidir, sobremaneira, sobre figuras e eventos históricos (Louis XVI, Revolução Francesa, Napoleão Bonaparte), sobre cataclismos provocados por fenómenos naturais (inundações, passagem de cometas, eclipses), sobre conflitos bélicos desencadeados pelo homem (guerras regionais e mundiais, bem como crises profundas na Igreja Católica) e sobre doenças gravíssimas, como, por exemplo, a gripe espanhola e a sida ${ }^{17}$. Numa das suas quadras, quadra 53 da centúria II, Nostradamus prevê a peste de Marselha ocorrida em 1720: "A grande peste da cidade marítima/ Não cessará enquanto a morte não seja vingada;/ Do justo sangue por tomado danado sem crime/ Da grande dama por ludíbrio não ultrajada. // (apud Fontbrune, 1981, p. 79). É surpreendente, todavia, que outro especialista (Prévost, 1999, p. 40) situe a

\footnotetext{
$17 \mathrm{Na}$ quadra 48 da quarta centúria, bem como na quadra 17 da oitava centúria, Nostradamus prevêa chegada de uma epidemia (sida ou outra?) e de uma peste associada à fome, ao fogo e ao sangue (Fontbrune, 1996, p. 87). Do mesmo modo, na quadra 55 da nona centúria há uma referência explícita à gripe espanhola (peste, doença contagiosa) (Fontbrune, 1981, p. 206).
} 
interpretação desta mesma quadra no passado, isto é, em 1545, cerca de cem anos antes da publicação de As Centúrias. Assim se confirma a dupla faceta de Nostradamus, profeta e historiador, que criticou os que não acreditavam nas suas previsões e afirmou que, no futuro - tenebroso, devido, sobretudo, à ameaça dos Muçulmanos -, quando vissem realizadas as suas visões, talvez começassem a acreditar nele.

No que respeita a Sainte Odille, há duas profecias, referindo-se uma ao Armagedão e uma outra à guerra ou vingança do Anticristo, que parecem corresponder àquelas a que Camus se refere: "As batalhas do passado serão apenas escaramuças quando comparadas com as batalhas que hão de vir... Fome e pestilência juntar-se-ão à guerra.” / "Um inevitável guerreiro irá desencadeá-la, e os seus inimigos chamar-lhe-ão Anticristo. Todas as nações da Terra combaterão umas contra as outras nesta guerra. Os combatentes erguer-se-ão nos céus, apoderar-se-ão das estrelas e lançá-las-ão sobre as cidades, queimando os edifícios e provocando uma imensa devastação. As nações gritarão 'paz, paz’, mas não haverá paz.” (1999, p.143-158).

Neste elenco de personagens, é impensável olvidar Tarrou, que, defensor de uma moral de compreensão, conhecedor de tudo o que há na vida e opositor à condenação à morte, aspira tanto à verdadeira paz interior, como à santidade sem Deus e, até, ao satanismo, como escreve nos seus Carnets: "Talvez só se possa alcançar uma aproximação da santidade. Neste caso, seria necessário que o homem se contentasse com um satanismo modesto e caritativo.” (idem, p. 250). Neste sentido, Lúcifer, o Príncipe do Mal, transforma-se, na sua ótica, em Príncipe de um Mal menor, ao surgir como o primeiro objetor de consciência. Rieux, por seu turno, torna patente o seu pragmatismo lúcido, desprovido de quaisquer ambições metafísicas, ao asseverar a sua solidariedade menos com os santos do que com os vencidos, ao não cultivar a 'religião' do heroísmo e da santidade e ao afirmar, de um modo perentório, que o que lhe interessa é ser um homem (idem, p. 230). Se este mundo não pertence a uma ordem superior, torna-se inegável que fora dele não há salvação - parodiando a célebre fórmula cristã "Não há salvação fora da Igreja” -, dado que “todo o nosso reino é deste mundo”, segmento frásico que se opõe ao ensinamento de Cristo: “O meu reino não é deste mundo”. Ora, se a peste abala a população de Orão, uma personagem há que sente a sua falta, posto que o fim da endemia corresponde ao fim do seu trabalho de contrabando: chama-se Cottard. 
Neste universo doentio, dois seres de papel, magistralmente esboçados, merecem uma referência, breve que seja: o asmático que tem à sua frente duas marmitas de ervilhas e o velho que tem o hábito de cuspir sobre os gatos.

Finda a peste, a vida em Orão regressa ao normal: aparece um rato vivo, um gato a lamber-se e um cão. Elevam-se, do porto obscuro, os primeiros festejos oficiais. Morreram Paneloux, Tarrou, Cottard e a esposa de Rieux. Outros continuam viver e a temer, como o Dr. Rieux, autor/grande escritor da narrativa que acaba no momento em que o leitor termina a sua leitura, e 'profeta' do reaparecimento, num futuro a vir, do bacilo da peste, que "nunca morre nem desaparece, que pode adormecer dezenas de anos nos móveis e na roupa, que espera pacientemente nos quartos, nas caves, nas malas [...] até que um dia virá em que, para infelicidade e ensinamento dos homens, a peste acordará os seus ratos e enviá-los-á para a morte numa cidade feliz.” (idem, p. 279).

A atualidade de La Peste é indubitável. Hoje, tal como em 1947, revemo-nos no romance camusiano, resistindo a um inimigo similar, tentando a todo o custo combatê-lo, fechando as fronteiras, decretando estados de emergência e calamidade, tomando sérias medidas sanitárias, obedecendo ao confinamento, sujeitando-nos à separação, resignando-nos às restriçóes e adaptando-nos paulatinamente a uma realidade outra. Além do mais, o que diria Camus (jornalista por necessidade e não por vocação) ${ }^{18}$ se soubesse que, no início do século XXI houve uma nova emergência de peste em Orão, tendo morrido uma criança de onze anos, conforme noticia o jornal Le Monde de 21 de junho de 2003?

Os tempos do Tempo são interessantes na sua circularidade intrigante. Cem anos volvidos sobre os 'loucos anos vinte', assistimos (e vivemos) a outros 'loucos anos vinte'; em 1920, passava-se da guerra à paz; agora, em 2020, passou-se da paz à guerra...

\section{REFERÊNCIAS BIBLIOGRÁFICAS}

A Bíblia de Jerusalém. (1981). São Paulo: Ediçôes Paulinas.

Barthes, R. (1993). CEuvres Complètes I. Paris: Seuil.

18 Ver Pia, 2010, p. 74-79. 
Cabral, M. J. (2020). Páginas antigas, a mesma história. A pandemia entre Literatura e Medicina. Semanário Sol, Opinião, 27.

Cabral, M. J. (2020), A máscara e o sopro. Semanário Sol, Opinião, 25.

Calvino, I. (2018). Pourquoi lire les classiques? Paris: Gallimard.

Camus, A. (1996). La Peste. Paris: Gallimard.

Camus, A. (2002). Lettres à un ami allemand. Paris: Gallimard.

Camus, A. (2003). Le Mythe de Sisyphe. Essai sur l'absurde. Paris: Gallimard.

Camus, A. (2006). CEuvres Complètes II. Paris: Gallimard.

Camus, A. (2013). CEuvres. Paris: Quarto Gallimard. [Dossier sobre La Peste].

Chevassus, N. (2017). Les origines du mal. Les Cabiers Science E̊ Vie. Les Épidémies, 170, 32-33, 61-65.

Fontbrune, J. C. (1981). Nostradamus. Historiador e Profeta. Lisboa: Editorial Presença.

Fontbrune, J. C. (1981). As novas profecias de Nostradamus. Mem Martins: Livros de Vida Editores, Lda.

Gaillard, P. (1972). La Peste. Paris: Hatier.

Guinle, J.-P. (1997). Les souverains de la France. Paris: Gallimard.

Hogue, J. (1999). O Livro das Profecias do Milénio. Lisboa: Círculo de Leitores.

Paveau, M.-A. (1996). La Peste. Paris: Bertrand-Lacoste.

Pia, P. (2010). Le Journalisme. Un boulot comme un autre. Le Magazine Littéraire, № 18, 74-79.

Prévost, R. (1999). Nostradamus. Le mythe et la réalité. Un historien au temps des astrologues. Paris: Robert Laffont.

Sá, J. (2008). A Crônica. São Paulo: Editora Ática.

Samson, C. (2010). Le véritable Nostradamus. L’homme qui a vu le futur. Clamecy. 